\title{
FIRST EXPERIENCES WITH OBJECT LESSONS IN NINETEENTH-CENTURY BRAZIL: ORIGINS OF A PROGRESSIVE PEDAGOGY FOR THE BRAZILIAN PRIMARY SCHOOL
}

\section{Primeiras experiências com o Manual "Lições de Coisas"no século XIX no Brasil: origens da pedagogia progressiva na escola elementar}

Karl M. Lorenz ${ }^{1}$

Aricle Vechia $^{2}$

\section{Abstract}

One can identify two great movements during the nineteenth century in which educational theories and practices were transplanted from Europe and the United States to Brazil. The first addressed the secondary school curriculum, and began with the founding of the Imperial College Pedro II in Rio de Janeiro in 1838. The college was created by the Imperial Government to, in part, serve as a model for private and public secondary schools in the provinces. Throughout the 1800s, French curriculum theory shaped the debates about the purpose, organization and content taught in the College, and to a larger extent, about the nature of secondary education in general. The second transnational movement centered on the method of teaching in the primary school.

Keywords: Secondary schools; Primary school; Curriculum.

ED Doctor, Sacret Heart University- Fairfeld - Connecticut e-mail: lorenzk@sacretheart.edu

2 Doutora em História Social, professora do Programa de Mestrado em Educação da Faculdade de Ciências Humanas, Letras e Artes da Universidade Tuiuti do Paraná - Rua Sidney Antônio Rangel Santos, 238, Santo Inácio, CEP: 82300-200, Curitiba/PR.

e-mail: avechia@ig.com.br 


\section{Resumo}

Durante o século XIX dois grandes movimentos caracterizam o ideário educacional: em primeiro lugar, a mudança no currículo da escola secundária e, posteriormente, na escola primária. Esses movimentos ocorrem tanto na Europa, como nos Estados Unidos e no Brasil. No Brasil concretizou-se por meio da reforma do currículo do ensino secundário, em 1838 no Colégio Pedro II, servindo de modelo para a privatização do ensino secundário. Além disso, esta reforma serviu de modelo para as escolas das províncias. As idéias pedagógicas que se constituíram como cerne dessa reforma originaram-se na França, servindo de inspiração para a organização da escola em geral. Nessa organização utilizaram-se as orientações do manual "Lições de Coisas", inspirado na tradução a adaptação de um manual chamado Primary Object Lessons de Norman Calkins, inserido na reforma de Rui Barbosa.

Palavras-chave: Escola secundária; Escola primária; Currículo.

One can identify two great movements during the nineteenth century in which educational theories and practices were transplanted from Europe and the United States to Brazil. The first addressed the secondary school curriculum, and began with the founding of the Imperial College Pedro II in Rio de Janeiro in 1838. The college was created by the Imperial Government to, in part, serve as a model for private and public secondary schools in the provinces. Throughout the 1800s, French curriculum theory shaped the debates about the purpose, organization and content taught in the College, and to a larger extent, about the nature of secondary education in general.

The second transnational movement centered on the method of teaching in the primary school. Ever since the Empire of Brazil was established in 1822, and the Constitution amended by the Additional Act in 1834, the responsibility for primary education fell to the provinces, while that of superior education was exclusively the domain of the Imperial Government. The provincial governments, however, failed to provide adequate primary schooling for its populaces. What typified education in the distressingly small number of schools throughout the realm were scant resources, a dearth of didactic materials, a predominance of verbal methods of instruction, and unprepared teachers. Brazilian legislators struggled with the problem of how to extend primary schooling to the masses and modernize the teaching methods in the classroom. At different moments, for example, they experimented with the Lancaster Method of teaching, and the Simultaneous Method, or whole group instructional method, neither of which was widely accepted (FARIA FILHO, p. 142143).

A significant event in the transformation of primary school pedagogy occurred in 1886 when Rui Barbosa, an ambitious and talented thirty-six year 
old Brazilian congressman published a manual on Object Teaching, titled Lições de Coisas. The text was a translation and adaptation of a manual called Primary Object Lessons, which was authored by Norman Calkins, a prominent American educator who was a vocal advocate of Object Teaching in the United States. The story recounting the origins of Calkins' manual and how it came to be popularized by Rui Barbosa is one of the more illuminating instances of how pedagogy is transplanted from one country and educational milieu to another.

\section{The Origins of the Primary Object Lessons}

Norman Calkins was an important figure in American Education during the second half of the nineteenth century. Immediately before the Civil War, he taught at Oswego College, in New York State, which was one of the first institutions in the country to explore Pestallozi's ideas on teaching children. Calkins was named Assistant Superintendent of Primary Schools of New York City in 1862, at which time he also taught a course, Principles and Methods, in the Saturday Normal School. He also was instrumental in founding the National Education Association, and became its president in 1886 (JOHNSON, p. 19-20).

While he was at Oswego College, Calkins published his first pedagogical work: Primary Object Lessons for a Graduated Course of Development (1861). The text provided suggestions on how to teach young children different academic subjects by using common objects. Nine years later, the manual was republished under the abbreviated title of Primary Object Lessons. It was this 1870 edition that became Calkins' signature work and established his reputation as one of the most influential proponents of Object Teaching and of Pestallozian-based pedagogy in the United States (LOURENÇO FILHO, p. 7576).

In the preface of his book, Calkins alludes to several great thinkers who shaped his view of teaching, the foremost of whom was Johann Heinrich Pestalozzi, the eighteenth century educational reformer. Calkins' interest in Pestolozzi was by no means unprecedented or an isolated phenomenon, since Pestalozzi's ideas had already transmigrated to the United States. In 1806, Joseph Neef, his friend when both lived in Burgdorf, introduced Pestalozzi's ideas to the United States. Neef was an avid proponent of Pestalozzi's theories and later was referred to as the "master's apostle in the New World." Beginning in the 1920s, Pestalozzi's ideas were advanced through the writings of John Griscom, William Woodbridge, De Boer, Harry Bernard, and Horace Mann (JOHNSON, p.18-19). Around 1860, the method attracted the attention of Edward A. 
Sheldon, Superintendent of Schools in the city of Oswego, New York, who came across a display of Pestalozzian instructional materials in Toronto, Canada. Sheldon acquired a set of the materials from England for use in training teachers in the Oswego school system.

It was at this time, while he was at Oswego College, that Calkins recognized the full potential of the new pedagogy. In his manual he informs the reader that he had examined several "systems of infant education" in Europe, especially those proposed by Wilderspin, Stow, and Currie, but that what most impressed him was the methodology employed by the English Home and Colonial Infant Society, and particularly the object lessons textbooks published by Elizabeth Mayo: the "Manual of Elementary Instruction" and "Model Lessons." Elizabeth Mayo wrote the texts after her brother, Reverend Charles Mayo, visited Pestalozzi's institute at Yverdon and upon returning to England, collaborated with his sister to open a Pestalozzian school.

On closer inspection, Mayo's manuals failed to completely reflect the Pestalozzian spirit since they were overly formal and analytic, and beyond the comprehension of the children (DE BOER, p. 22). Nevertheless, Calkins was impressed with the texts. He was also aware of their deficiencies, and this led him to produce a manual that more accurately promoted the Pestalozzian pedagogy. Calkins noted that primary school teachers had little or no instruction on the mental powers of the child, nor the training to teach "real things, real forms, real colors, real sounds, and words to represent them, and how to lead the mind to correct conceptions" (CALKINS, 1872, p. 20). Instead, their preparation consisted mainly of learning the content that they would teach in the schools. His manual was designed to fill this void by elucidating a "system of mental development" in accordance with the "philosophical principles" suggested by Pestalozzi (Johnson, 1977, p. 11-18), and by outlining a method that would be appropriate for teaching most school subjects to young children (CALKINS, 1872, p. 6-7).

Calkins' believed that any method used to teach children should take into account the natural way the child learns. "The instruction," he writes, "should fall in with the child's desire to know, and allow it to exercise its senses upon each new object presented to it, by seeing, feeling, hearing, tasting, or smelling it..." (CALKINS, 1872, p.18). Essentially, it is "things before words", i.e. presenting to the child the things with which he is already familiar and from there deepen his knowledge of the world until he is in the position to verbalize what he experiences. For example, before teaching the word "cube" the child should be familiar with and be able to distinguish the form of a cube. Or before learning the words "rough" and "smooth", the child should experience roughness and smoothness in objects. 
Within the first few pages of the Primary Object Lessons, Calkins confidently asserts that "The laws of mental development are just as certain, and may be clearly understood, as the laws of physical growth," and that it is possible to develop a system of teaching that is in accordance with them (CALKINS, 1872, p. 23). He then outlines the principles, or "facts" as he characterizes them, that support his methodology.

1. All knowledge of the natural world is obtained through the senses; objects and phenomena of the natural world are the subjects of sensate experience.

2. The "mental powers" that are as active in the child as in the adult are "sensation, perception, observation, comparison, simple memory, and imagination" For the child, knowledge first manifests itself when "resemblances and differences" in objects are perceived, and knowledge deepens as the comparative ability increases, as well as the ability to 'classify and associate objects, experiences, and facts that resemble each other." In this way knowledge is attained.

3. The natural process of education is from the simple to the complex; from the known to the kindred unknown; from facts to causes - things before names; ideas before words; principles before rules.'

4. The "natural and most healthful" incentive to learning is the association of pleasure with instruction. Gratification is felt when a child's natural and inherent disposition of curiosity, or the natural craving for knowledge, is satisfied.

5. "Habits of attention," that are formed through repetition of the same act, are the foundations of a child's education. And securing the attention of children can be achieved by "arousing their curiosity, and gratifying their love of activity" (CALKINS, 1872, p.15-17).

Calkins incorporated these principles in the Primary Object Lessons, as evidenced by the manual's focus and organization. After an introductory chapter that discusses home training, introductory school lessons, conversational exercises, and exercises for training in habits of thinking and speaking promptly, the manual is divided into the following sections: form, color, number, size, drawing, time, sound, primary reading, qualities of objects, human body, and moral training. For topics in each section, Calkins presents a set of graded lessons and exercises, each of which is comprised of a sample script that a teacher might follow when verbally interacting with the child, and suggestions on method. The teacher-child discourse centers on objects or phenomena that the child is encouraged to explore; that is the child is prompted to observe, describe, compare and contrast, identify related phenomena, etc. (CALKINS, 1872, p. 121-122). 
The Primary Object Lessons was an immediate success, and for decades it enjoyed enduring popularity with educators, both in the United States and abroad. By 1898 it had passed through 40 editions in the United States, alone. The text had been praised and recommended by Buisson, the French Minister of Instruction; and it had been translated into Japanese in 1877, and into Spanish in 1872 and 1879 (VALDEMARIN, p. 118). As it will be shown in the next part of this presentation, Calkins' manual was also adopted in Brazil, where it made a significant contribution to Brazilian education reform in the 1890s and early 1900s.

\section{The Origins of the Lições de Coisas}

Rui Barbosa was a lawyer and journalist from the tropical, northeastern state of Bahia. In 1879 he was elected to the national Chamber of Deputies as the Liberal Party representative from Bahia. During the final years of the Empire and the beginning decades of the First Republic, his erudition, oratorical skills and singular capacity to analyze profound political and social questions made him the preeminent public figure of his time, one that few could match in stature or persuasive power. Brazilian literature recognizes his extraordinary abilities and place in history by calling him the "Greatest Intellect of the Epoch," or "The Eagle of the Hague" and other complimentary titles. But the label that he wore most proudly was that of "Liberal" - a defender of the modernizing forces that sought to transform Brazil from an empire to a republic (VALDEMARIN, p. 25-26).

In 1880, Barbosa was named to the Commission on Public Instruction, which was charged with examining the educational reforms proposed by the Minister of the Empire, Le?hcio de Carvalho. In government decrees issued in 1878 and 1879, Carvalho reorganized Brazilian education, from kindergarten through the superior schools. Among the dispositions of the 1879 decree, he expanded the primary school curriculum and the programs of study in the teacher normals. For inspiration, he looked to educational practices in Europe and the United States, and to progressive methodologies used in some private Brazilian schools. Comprising this latter group were a handful of kindergartens that applied the ideas of Froebel, and a few primary schools that promoted varying forms of Object Teaching.

With an assuredness of purpose, cultivated by his familiarity with pedagogical innovations abroad and in Brazil, Carvalho introduced a subject called "notions of things," into the first years of public primary schools in the Municipality of the Court. This subject consisted of an exploration of natural and man-made phenomena as preparation for later studies. Carvalho also es- 
Firts experiences wirh object lessons in nineteenth-century Brazil: origeins of a progressive pedagogy...

tablished in the teacher normals methodology courses entitled "Practice of Primary Teaching in General" and the "Practice of Intuitive Teaching or Object Lessons." This was a significant change for these institutions, since until then the curriculum was organized to only ensure the students' mastery of the content they would teach. As a result, little attention was directed towards the methods of instructing children at different stages of their development.

To coincide with the changes in the curriculum, Carvalho argued for the adoption of progressive manuals on methodology. Several French texts on the Intuitive Method were circulating at the time and available to Brazilian teachers, but as Barbosa noted in the preface to his own book, they "were far from corresponding to the requirements of the method that its title assumes." One of these works was that of Fanny and Charles Delon, the Méthode intuitive. Exercices et travaux pour les enfants selon la méthode et les procédés de Pestalozzi et de Froebel (1873). Another text was published by Jules Paroz under the title Plan d'etudes et leçons de choses pour les enfants de six à neuf ans (1875). A third text, which was in evidence as early as the 1860's, was a translated version of a Charles Saffrey's Leçons de choses. What these and other similar texts had in common was their representation of Object Lessons as content to be taught, rather than as applications of a methodology that transcends content (VALDEMARIN, p. 42-43).

As the leading member of the Commission on Public Instruction, Barbosa assumed the responsibility of writing up the findings of the Commission. He produced two reports: the first was on higher education and appeared in 1881, and the second was on primary and secondary education, which followed in 1882. In the 1882 report, Barbosa not only critiqued the Carvalho reform, he also offered a substitute proposal for reorganizing primary education (LOURENÇO FILHO, p. 45). His reflections on this issue inexorably led him to the conclusion that a change in teaching methodology was a necessary adjunct to change in the structure and organization of the primary school (LOURENÇO FILHO, p. 34). Challenged by his own logic, Barbosa turned to Norman Calkins' text, for he found in the manual the methodology he required for his proposal.

When Barbosa obtained a copy of Calkins' text is unclear; how he first became aware of the manual, on the other hand, is somewhat less murky. We know that Barbosa had read about the Primary Object Lessons in a report by the French Minister of Public Instruction, Ferdinand Buisson, who praised the text after perusing it at the 1876 Philadelphia Exposition. Buisson considered it the best of its genre and recommended it for use in French schools (JOHNSON, p. 21-22). Barbosa undoubtedly had read Buisson's report as part of his background research for the Commission, and he was not shy about including the Minister's laudatory remarks in the preface of his own text, the Lições de Coisas. 
However, there is another possible and more tantalizing explanation of how Calkins's text came to Barbosa's attention. As a member of the Commission of Public Instruction, Barbosa had visited a number of private and public schools in the Municipality of the Court. During one of these visits he was particularly impressed with the Collegio Progresso (Progress College), which had been referred to him to him by his cousin and good friend, Antonio de Araújo Ferreira Jacobina, whose oldest daughter was enrolled at the school. The college was a private school for girls, located in Santa Teresa, a quite residential district overlooking greater Rio de Janeiro and Guanabara Bay. It was administered by an American, Mrs. Eleanor Leslie Hentz.

During his visits to the school, Barbosa found himself increasingly impressed with the method of teaching used in the classroom Johnson (p. 18), and had on one occasion even invited the former Minister of the Empire, Rodolfo Dantas, to attend a lesson on geography. It is highly probable that Barbosa and Mrs. Hentz conversed extensively about the finer points of Pestallozian pedagogy, and that these stimulating conversations convinced Barbosa of the necessity of divulging this method to other schools (LOURENÇO FILHO, p. 74). Since Calkins' text was already in use in the United States for some time, it is not unreasonable to conclude that Hentz and Barbosa had the text in hand as they discussed its merits and its applicability to Brazil. It was then that Barbosa took the first steps to popularize the text in Brazil.

In 1881, in a remarkably short eight weeks, Barbosa completed an adaptation and translation of the Primary Object Lessons, and called it the Liçoes de Coisas. With regards to adapting the text for use in Brazil, Barbosa changed the English system of measurement to the metric system, and introduced his own section on the sounds of the language, since Calkins' system of sounds did not apply to the Portuguese language (CALKINS, 1952, p. 18).

In February 1882, the imperial government approved Barbosa's text for use in the schools of the Municipality of Rio de Janeiro, but with a change of government in June, no further action was taken until 1884 when the new Minister of the Empire, Felipe Franco de Sá, authorized the National Typography to publish 15,000 copies of the work. From this total, Barbosa received 12,000 copies for sale and distribution, and the government retained 3,000 copies, also for sale, to cover the cost of producing the text. The composition and printing of the manual was completed in 1885, and distribution began in April 1886 (JOHNSON, p. 41).

The Lições de Coisas enjoyed considerable success in Brazil, and for many years was the most widely disseminated teacher's manual in the country (JOHNSON, p. 11-12). The text passed through various editions, and during the final years of the Empire and the greater part of the First Republic, it was the only officially sanctioned teaching manual in Brazil. It was commercialized 
and widely disseminated in the provinces, especially in Rio Grande do Sul and in São Paulo. Later, records show that the manual was used in the primary schools and normal schools in the State of Bahia in the 1920s, and in the State of São Paulo as late as the 1930s (JOHNSON, 42-43). In addition, excerpts of the manual were published in numerous educational journals and magazines during these years. One notable journal, circa 1915, praised the manual as being the "best pedagogical guide available today (JOHNSON, p. 44).

The great Brazilian educator, Lourenço Filho, describes the Lições de Coisas as Barbosa's first and most comprehensive work on education. He might have added that it was also the last educational text that Barbosa penned (CALKINS, 1952, p. 30). After the publication of the manual in 1886, Barbosa never again devoted himself with such single-minded dedication to educational issues. Rather, his interest turned to matters of State, beginning with his drafting of the constitution for the Republic that was declared in 1889.

\section{Final Considerations}

This paper has outlined a sequence of events in which a methodology based on Pestallozian pedagogy was popularized in Brazil. A seemingly linear set of events exemplifies how foreign educational theories and practices can move across borders and influence host national educational policies. This particular sequence began with the creation of a child-oriented pedagogy in Switzerland, continued with its application in schools in England and the United States, and concluded with the publication of the Primary Object Lessons. Then, the linear sequence continues as Calkins' manual was discovered by Barbosa at the Collegio Progresso and in the Buisson report, and then translated and published in Brazil as the Lições de Coisas. The chain of events herein described is but one of several trajectories that resulted in the introduction of foreign teaching methodologies to Brazil in the $19^{\text {th }}$ century.

\section{References}

BARBOSA, R. Reforma do ensino primário e várias instituições complementares da instrução pública. Obras Completas. Rio de Janeiro, RJ: MEC, 1947. v. 10. t. 1-4.

CALKINS, N. A. Primary object lessons, for training the senses and developing the faculties of children. New York: Harper and Brothers, 1872. 
CALKINS, N. A. Primeiras Lições de Coisas. Obras Completas de Rui Barbosa. Rio de Janeiro, RJ: MEC, 1950. v. 13. t. 1.

FARIA FILHO, Luciano Mendes de. Instrução elementar no século XIX. In: LOPES, Eliane Marta Teixeira, et. al. 500 anos de educação no Brasil. Belo Horizonte: Autêntica, 2000.

JOHNSON, Phil Brian. Rui Barbosa e a reforma educacional: as lições de coisas. Rio de Janeiro, RJ: MEC, 1977.

LOURENÇO FILHO, M. B. A pedagogia de Rui Barbosa. São Paulo, SP: Melhoramentos, 1966.

VALDEMARIN, Vera Teresa. Estudando as lições de coisas: análise dos fundamentos filosóficos do método de ensino intuitivo. Campinas: Autores Associados, 2004.

Recebido em: 30/07/2004 Aprovado em: 30/11/2004 